\title{
Distinguishing between Traditional and Online Retailing: Evaluating E-commerce with Respect to the Food System 1
}

Angelina C. Toomey and Allen F. Wysocki ${ }^{2}$

\section{Introduction}

Online shopping continues to grow in popularity, especially among women and other target demographics, such as the 18- to 25-year-old set (The Economist 2004). Many retail outlets have begun using electronic data interchange systems - the Internet and e-mail - to sell goods and services, a practice called electronic commerce, or e-commerce.

Items from clothing and shoes to mattresses and food are being bought and sold through various e-commerce formats. In fact, some retailers are opting out of the traditional storefront format entirely to participate in e-commerce, citing lower costs to both businesses and consumers alike.

However, not every item can be successfully sold online. Food, in particular, is an item placed under heavy scrutiny in the marketplace, including in the online sales arena. Therefore, it is important for businesses considering a shift to exclusive online sales or the incorporation of e-commerce into current business operations to understand the differences between e-commerce and traditional commerce and the characteristics of successful e-commerce operations. It is also essential for such businesses to be able to identify special considerations, regarding food sales and e-commerce. This article will focus on business-to-consumer (B2C) practices, and in particular, B2C methods of e-commerce with respect to online food sales.

\section{Differences between E-commerce and Traditional Commerce}

One interesting difference between e-commerce and in-store sales is that consumers often associate online shopping with "deals" or lower prices, due to auction sites and easy cross-referencing via search engines. In addition, using the Internet to purchase goods or services facilitates consumer competition because of greater accessibility. In other words, while consumers can visit only a few traditional outlets per day, they have access to countless Web retailers in the same timeframe. Because of the ease of access to many retailers and greater opportunities for bargain-hunting, "[c]ompetition on the web is fierce. Price transparency is the rule. With

1. This is EDIS document FE820, a publication of the Food and Resource Economics Department, Florida Cooperative Extension Service, Institute of Food and Agricultural Sciences, University of Florida, Gainesville, FL. Published December 2009. Please visit the EDIS website at http://edis.ifas.ufl.edu.

2. Angelina C. Toomey, Extension 4-H agent, Broward County, Davie, FL, and Allen F. Wysocki, associate professor, Food and Resource Economics Department, Florida Cooperative Extension Service, Institute of Food and Agricultural Sciences, University of Florida, Gainesville, FL.

The Institute of Food and Agricultural Sciences (IFAS) is an Equal Opportunity Institution authorized to provide research, educational information and other services only to individuals and institutions that function with non-discrimination with respect to race, creed, color, religion, age, disability, sex, sexual orientation, marital status, national origin, political opinions or affiliations. U.S. Department of Agriculture, Cooperative Extension Service, University of Florida, IFAS, Florida A. \& M. University Cooperative Extension Program, and Boards of County Commissioners Cooperating. Millie FerrerChancy, Interim Dean 
shopping-comparison services, it is possible to check the price offered by hundreds of merchants with a couple of mouse clicks" (The Economist 2004).

Another difference between e-commerce and traditional selling is the consumer's immediate access to information. "Consumers have access to an unprecedented amount of product information, not just from manufacturers' websites but also from online reviews written by previous customers, employees, and organizations faster, more directly, and with more visibility than ever before" (The Economist 2004).

Still a larger difference between traditional commerce and e-commerce exists because information technology (IT) is the middleman, with IT acting as a facilitator for globalization and integration (Kersten 2008). Differences also exist in terms of costs to consumers and retailers. For example, shipping is usually charged but not sales taxes, depending on the state or whether a storefront exists in the marketplace. In addition, face-to-face interaction usually does not exist in online retailing. Similarly, online retailers must rely on different skill sets to effectively market to their target audiences. For example, instead of facilitating taste tests to help sell a particular product, online retailers would use Internet pop-ups or e-mail blasts with promotional codes to feature a specific item.

The differences between e-commerce and traditional in-store sales may still pose difficulties for some consumers, but it is important to know that consumer perceptions are steadily shifting in a positive way toward online retailing. In general, "[c]onsumers are behaving as if they see no great distinction between online and offline shopping. They do both. For most consumers, the internet is just another sales channel, and a convenient tool for browsing and research, and they make their purchase in whatever way happens to suit them best" (The Economist 2004). That being said, some areas of online retailing, such as food sales, are slower to be adopted. Reasons for a lack of acceptance will be addressed later in this article.

\section{Characteristics of Successful E-commerce in the Food Industry}

Due to the differences between e-commerce and traditional commerce regarding the food system, it is important for current and potential online vendors to understand the three keys to successful e-commerce:

1. Trust: Due to foodborne illness and other concerns regarding food safety, e-commerce retailers must be reputable and trustworthy. This is because consumers may perceive the costs of purchasing food online as greater than doing so in traditional formats due to health risks associated with food mishandling or lengthy shipping times. To encourage consumer trust, retailers can use e-commerce to make efficiency improvements in the food chain (Fritz 2007).

2. Timeliness: Successful e-commerce companies understand that information must be continuously updated to enable consumers to patronize their sites. Information regarding purchase prices, available and backordered foods, and discontinued items should be readily available. Products should be delivered in a timely manner, and food recalls should be swiftly addressed. Otherwise, consumers may be dissatisfied with their online food shopping experience. To quote one shopper: "Of course, there would be differences when items are replaced, although upon checking my original order and the prices charged, what I found was that the site was not updated regularly enough to reflect real prices in today's market. This really is misleading, and it's important to check that the prices shown are current" (de Bretagne 2008).

\section{Partnerships: "The key to successful} e-commerce for the food and drink industry lies in linking manufacturers' marketing and promotional skills with retailers' transactional and fulfillment expertise" (Business Insights 2001). In other words, effective partnerships between online retailers and marketers are vital to the success of e-commerce in the food system. By using the skills and strengths of each industry, e-retailers can create recognizable and highly regarded brand identities, which will in turn facilitate online food sales. 


\section{Things to Keep in Mind When Developing an E-commerce Operation}

Despite having the potential for success, e-commerce in the food system still faces several challenges for which solutions are emerging. The following should be kept in mind when considering the creation and development of an e-commerce operation:

1. Consumer perception of quality is still lacking when purchasing food online. For example, how fresh are groceries bought online? Fruits and vegetables bought in supermarkets can be tested for freshness by touching and/or smelling. This is not possible online (de Bretagne 2008).

2. Consumers are worried that they may receive incorrect items or inferior substitutions (de Bretagne 2008).

3. There is a lack of face-to-face interaction in e-commerce, which may be necessary for food transactions. Consider the following: if consumers need information about food allergens, who do they ask for help?

4. The target audience is particularly important in food-related e-commerce. Regional or ethnic foods, especially those that are perishable, need to be closely monitored. Communication may be delayed by slow Internet connection speeds.

5. Few perishable food items are sold via online retailers. Most perishable foods sold online are items that command a premium in the marketplace or that are not readily available in retail outlets. In general, shelf-stable items such as canned goods tend to be more suitable for sale online.

6. Shipping is a double-edged sword with respect to food-related e-commerce. High shipping costs can deter customers and bring down an e-retailer's profit margins (Tedeschi 2006).

\section{Concluding Remarks}

E-commerce related to food purchases is a relatively new concept and one that has yet to be fully embraced. The benefits of e-commerce in B2C food transactions must be carefully weighed against the costs. While the potential for successful online food vendors does exist, e-commerce startup costs may be high and losses even higher, especially in terms of perishable food, so it is important for each firm to evaluate its short-term and long-term goals.

Incorporating e-commerce into a traditional operation is not for everyone. Retailers must consider each of the aforementioned factors before starting an online food business.

All successful e-commerce depends on solid, trustworthy partnerships and timely operations, and online retailing of food is no exception. As online shopping continues to grow, it is likely that an increasing number of buyers will use food industry e-commerce services. Online food purchases must be shown to be as safe and of the same quality as in-store transactions. The success of e-commerce relies upon two things: buyer preference and perceived safety of purchases. Until these aspects of online food transactions are effectively addressed, traditional buying formats will continue to dominate both the marketplace and marketspace.

We hope you have found this article useful. We invite you to provide feedback via e-mail (angelinactoomey@ufl.edu or wysocki@ufl.edu). Your comments and suggestions are always welcomed.

\section{Resources}

To learn more about e-commerce and e-commerce with respect to the food industry, search the following Internet sites:

1. Basic Guide to E-commerce (Doing Business

Over the Internet/Web): http://www.managementhelp.org/infomgnt/ e_cmmrce/e_cmmrce.htm

2. E-commerce Times: E-business Means Business: http://www.ecommercetimes.com/ 
3. Foodzie (YouTube clip):

http://www.youtube.com/

watch?v=38ZtFTSNVhk

\section{References}

Business Insights. 2001. Best practice B2C

e-commerce in food and drink: Online strategies to meet the demand of your consumers.

http://www.globalbusinessinsights.com/content/ $\underline{\text { rbcg0053m.pdf }}$

de Bretagne, R. (2008). Bad experiences with shopping grocery online.

http://www.helium.com/items/291261-bad-

experiences-with-shopping-grocery-online 2004. Leaders: E-commerce takes off. The Economist 371(8375): 9 (May 15).

Fritz, M. 2007. E-commerce partnering due diligence: A methodology for trust in e-commerce in food networks. Acta Agriculturae Scandinavica 4(1): 13-20.

Kersten, G.E. No Date. A few suggestions for the Canadian agenda on e-commerce. Department of Decision Sciences and MIS, Concordia University, Montreal.

http://interneg.concordia.ca/interneg/research/papers/ 1999/11.pdf

Tedeschi, B. 2006. E-commerce report; after delving into 32 other lines, Amazon finally gets around to food. The New York Times Online (October 15).

http://query.nytimes.com/gst/

fullpage.html?res=9900E6D9143FF937A15754C0A9 609C8B63\&sec=\&spon=\&pagewanted=all 